Review

\title{
Juglone in Oxidative Stress and Cell Signaling
}

\author{
Taseer Ahmad ${ }^{1}$ and Yuichiro J. Suzuki ${ }^{2, *}$ \\ 1 College of Pharmacy, University of Sargodha, Sargodha, Punjab 40100, Pakistan; drtasir2011@gmail.com \\ 2 Department of Pharmacology and Physiology, Georgetown University Medical Center, Washington, \\ DC 20007, USA \\ * Correspondence: ys82@georgetown.edu; Tel.: +1-202-687-8090; Fax: +1-202-687-8825
}

Received: 25 February 2019; Accepted: 1 April 2019; Published: 5 April 2019

\begin{abstract}
Juglone (5-hydroxyl-1,4-naphthoquinone) is a phenolic compound found in walnuts. Because of the antioxidant capacities of phenolic compounds, juglone may serve to combat oxidative stress, thereby protecting against the development of various diseases and aging processes. However, being a quinone molecule, juglone could also act as a redox cycling agent and produce reactive oxygen species. Such prooxidant properties of juglone may confer health effects, such as by killing cancer cells. Further, recent studies revealed that juglone influences cell signaling. Notably, juglone is an inhibitor of Pin1 (peptidyl-prolyl cis/trans isomerase) that could regulate phosphorylation of Tau, implicating potential effects of juglone in Alzheimer's disease. Juglone also activates mitogen-activated protein kinases that could promote cell survival, thereby protecting against conditions such as cardiac injury. This review describes recent advances in the understanding of the effects and roles of juglone in oxidative stress and cell signaling.
\end{abstract}

Keywords: antioxidants; juglone; naphthoquinone; Pin1; redox; signal transduction; walnuts

\section{Introduction}

Archaeological data suggest that the gathering and intake of walnuts by humans occurred as early as 7300 years ago in the Mediterranean [1]. The use of walnuts in traditional medicine suggests the presence of multiple, effective, and useful compounds which may provide health benefits such as antihypertensive, endothelial protective, anti-diabetic, and hepato-protective activities [2-5]. Walnuts contain various phytochemical constituents that may promote human health. The walnut is a dietary plant with one of the highest levels of antioxidants [6], and it has the highest level of phenolic antioxidants among nut species [7-9]. Walnut extracts have been found to contain flavonoids, terpenoids, gallic acid, caffeic acid, myricetin, and quercetin as well as naphthoquinones like juglone [10-13].

Juglone (5-hydroxy-1,4-naphtoquinone; see Figure 1 for the chemical structure) is found in the fresh ripe fruit husk, roots, leaves, and bark of walnut trees [14,15]. Juglone is produced by the numerous species of walnut tree including the Juglans nigra (black walnut), Juglans regia (English or Persian walnut), Juglans sieboldiana (Japanese walnut), and Juglans cinerea (butternut or white walnut) [16]. Juglone is also found in Carya ovata (hickory tree), Proteaceae [17], Caesalpiniaceae [18,19], and Fabaceae [20]. Most studies refer to the use of Juglans nigra for isolation of juglone and allelopathic studies because this particular species produces the largest amount of juglone [21]. 


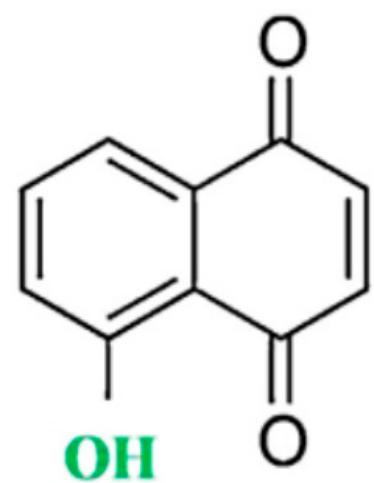

Figure 1. Chemical structure of juglone.

It was not until the 1850s that juglone (then termed "nucin" from the Latin nux, meaning a nut) was first isolated from the walnut tree [22], and in 1881 the first scientific report on the allelopathic effect of juglone was published [23]. Further, juglone has been found to have various pharmacological actions, including a depressant effect [24], an impact on skin diseases [16], and antimicrobial [25], anti-cancer [26-28], anti-fungal [25], and antioxidant [29] activities, as well as apoptotic capacities [30] and anti-angiogenesis properties [31]. Juglone and its derivatives have been shown to possess the ability to inhibit food degradation by creating resistance to oxygen and its reactive species [29].

In this review, the redox properties of juglone in relation to its health benefits will be discussed. We also summarize the published results on the effects of juglone on cell signaling.

\section{Antioxidant Properties of Juglone}

Through the production of reactive oxygen species (ROS), biomolecules undergo oxidative stress. Antioxidants reduce ROS, and the balance between ROS and antioxidants defines oxidative stress. Phenolic compounds can inhibit these reactions by directly quenching ROS, inhibiting ROS producing enzymes, chelating transition metal ions, hydrogen atom transfer, and regeneration of vitamin $\mathrm{E}$ as depicted in Figure 2 [32-34]. The intramolecular hydrogen bonds play important roles in the stability of free radicals [33,35-37]. Juglone contains an intramolecular hydrogen bond between hydroxyl and keto groups and is active in donating the hydrogen-atom [38]. Juglone may have either pro- or antioxidant characteristics depending on the concentrations [29]. Thus, some studies reported the generation of ROS by juglone, while others describe its antioxidant properties [39].

Some antioxidants are capable of chelating transition metal ions (especially $\mathrm{Fe}^{2+}$ and $\mathrm{Cu}^{+}$) leading to the formation of stable complexes, thereby preventing these metals from participating in free radical generation [33,40-42]. Ferrous iron promotes lipid oxidation through Fenton reaction [43]. To avoid metal-catalyzed oxidation, the use of natural metal chelators instead of the synthetic counterparts should be encouraged [32]. It has been revealed experimentally that deprotonated juglone has the capacity to chelate $\mathrm{Fe}^{2+}$ [44].

Accumulating evidence suggest that antioxidant properties of juglone are useful in combating oxidative stress-linked diseases. Juglone has been shown to prevent oxidative and heat stress-induced dephosphorylation of Tau (an important step in the pathogenesis of Alzheimer's disease) in in human cortical neurons [45]. A recent study in a transgenic mouse model of Alzheimer's disease demonstrated that the walnut supplementation can reduce oxidative damage [46]. Oxidative stress is an important mechanism for kidney fibrogenesis [47,48], and Reese et al. reported that juglone reduces oxidative stress by inhibiting the phosphorylation of Smad2 in the kidney [49]. Zhou et al. [50] demonstrated that juglone increased the activity of superoxide dismutase and decreased oxidative stress in the liver. The authors also observed that juglone reduced the serum levels of alanine aminotransferase, aspartate amino-transferase, hyaluronic acid, laminin, type III procollagen, and type IV collagen and the expression levels of $\alpha$-smooth muscle actin and collagen III in the liver [50]. 


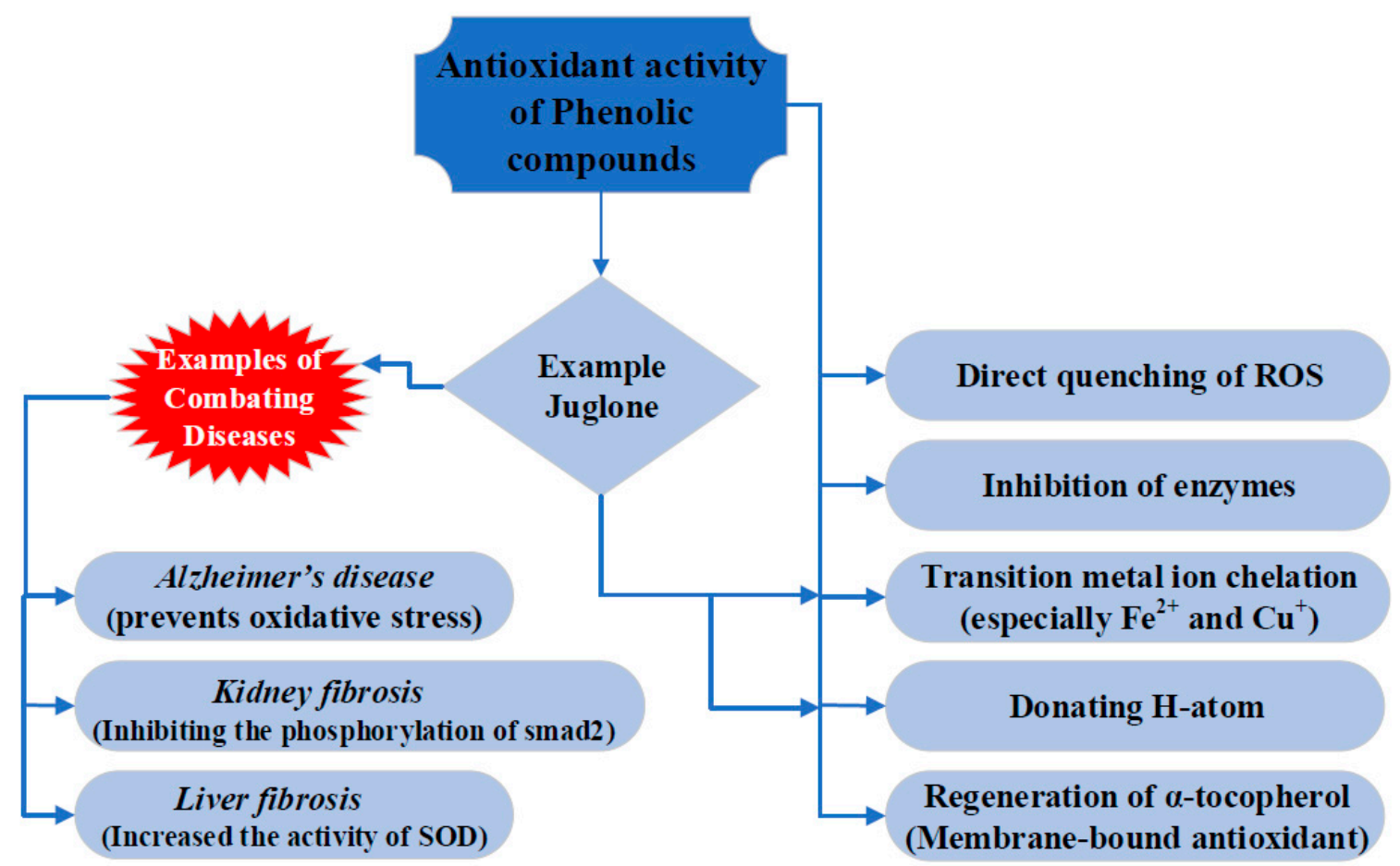

Figure 2. Schematic diagram describing the antioxidant properties of phenolic compounds including juglone.

\section{Juglone as an Oxidant: Cytotoxic Potential}

The generation of ROS and modulation of redox signaling are properties of quinones that render them interesting leads for the development of novel compounds of potential use in various therapeutic sites [51].

Many quinoid compounds such as naphthoquinones have pharmacological and toxicological importance [52,53] because of their electrophilicity and redox properties. Naphthoquinones have been shown to possess cytotoxic [54,55], antitumor [56] and antimicrobial activities [25,57,58]. Naphthoquinones are among the most active natural products obtained from plants and microorganisms, and they exert their biological activities through pleiotropic mechanisms that include reactivity against cell nucleophiles, generation of ROS, and inhibition of proteins [59].

Juglone is a natural toxin produced by walnut trees [60]. Numerous proposals have been made to explain the mode of action underlying the cytotoxicity of juglone [61]. Although this molecule has multiple effects, including apoptosis [62], it is well known that these effects are cell-type-specific [60] and the exact mechanism remains unclear. According to Aithal et al. [63], the cytotoxic and genotoxic effects of juglone involve the induction of oxidative stress, cell membrane damage, and apoptosis and necrotic cell death. Supporting the theory that juglone causes oxidative stress, a small amount of juglone rapidly oxidizes a large amount of reduced nicotinamide adenine dinucleotide phosphate $(\mathrm{NADPH})$ when added to rat liver microsomal preparations rich in one-electron reductases. This results in a large increase in oxygen consumption and ROS production. These events are prevented by pre-treatment with inhibitors of NADPH reductases [64]. Moreover, the cytotoxicity of juglone requires bioreduction to yield the semiquinone, which in turn reduces oxygen to superoxide [65].

Naphthoquinones, especially juglone are also considered as myotoxic quinones, which have been found to undergo rapid single-electron reduction [66]. This effect is also validated by the study in which the mammalian selenoprotein thioredoxin reductase 1 (TrxR1), a key enzyme in redox regulation, antioxidant defense, and cellular growth, catalyzes efficient reduction of juglone in a reaction. One-electron juglone reduction by TrxR1 produces superoxide and further contributes to the pro-oxidant cytotoxicity of juglone [67]. 
Some studies also reported that the cytotoxicity of juglone is due to two different mechanisms, namely, redox cycling and the reaction with glutathione (GSH) [14]. Redox cycling represents a cyclic process of reduction of a compound, followed by oxidation of the reaction product and the simultaneous generation of ROS [68]. Juglone enhances lipid peroxidation predominantly through redox cycling [69]. The second mechanism of the toxicity of juglone is the formation of adducts, which also causes the glutathione depletion. Juglone can also form adducts with nucleophiles via Michael-type addition to the quinone. The thiol group on reduced glutathione is a very good nucleophile, and it is easily arylated by juglone. Arylation of reduced glutathione by juglone increases cellular toxicity by decreasing the availability of reduced glutathione, an endogenous antioxidant $[51,70,71]$.

Different studies confirmed the cytotoxic effects of juglone against the various types of human cell lines. Cytotoxic effects of juglone have been studied on human leukemia cell (HL-60 and HL-60R). The multidrug resistance developed by the doxorubicin-resistant HL-60 cell line did not prevent the cytotoxic effect of juglone [61]. Juglone exhibited cytotoxicity to human hepatoma cell line, HepG2, and the BALB/c mouse fibroblast cell line, 3T3 [72]. Juglone also differentially reduced the viability of human cells in culture through the induction of DNA damage, the inhibition of transcription, the reduction of p53 protein levels, and the induction of cell death [60]. Juglone exerted cytotoxic, anti-proliferative, and anti-invasive effects on C6 rat glioma cells in vitro [73].

Furthermore, the 5-hydroxy semiquinone free radical, superoxide, and hydroxyl radical (product of the Fenton reaction) have all been directly observed in human keratinocytes by electron paramagnetic resonance. Additionally, pretreatment with buthionine sulfoximine, an inhibitor of glutathione synthesis, decreases antioxidant availability and sensitizes cells to juglone toxicity [14]. The reverse of this is also true: pre-treatment of human leukemia cells (HL-60) with $\mathrm{N}$-acetylcysteine, an antioxidant, prevents juglone-induced death [74]. Collectively, these results strongly support the importance of redox cycling and ROS in the cellular toxicity of juglone. However, it should be noted that the actions of antioxidants can be complex. Ascorbic acid (vitamin C) has recently been shown to potentiate the cytotoxicity of juglone by increasing the efficiency of redox cycling. Nevertheless, several decades of literature support the prevention of quinone toxicity by pretreatment with antioxidants. [75-78].

\section{Anticancer Effects of Juglone}

Quinones are plant-derived secondary metabolites that produce some anti-proliferation and anti-metastasis effects in various cancer types [79]. Several anti-cancer drugs contain the quinone nucleus and have proven useful in cancer chemotherapy [80]. Quinones are among the most frequently used drugs to treat human cancer. They undergo reversible enzymatic reduction and oxidation, and form semiquinones and oxygen radicals, thereby promoting oxidative stress and damage to tumor cells [81]. The antitumor activity of quinones is frequently linked to DNA damage caused by alkylating species or oxygen radicals [53]. Some important drugs used for the treatment of cancer belong to the quinone class of organic compounds, like daunorubicin and doxorubicin [82]. Natural quinones like 1, 4-naphthoquinones [83] seem to be promising for targeting cancer cells [84].

The plant source of juglone, juglans regia, has been found to possess an anticancer capacity [85]. Thus, the isolated active chemical constituent, juglone, has been investigated in different human cancer cell lines (Figure 3). Since ROS play diverse roles in cancer, modulating the redox status of cancerous cells seems to be a promising therapeutic approach. The published data revealed that the cancer-related inhibitory effects of juglone are associated with enhanced ROS production and lipid peroxidation [78]. 


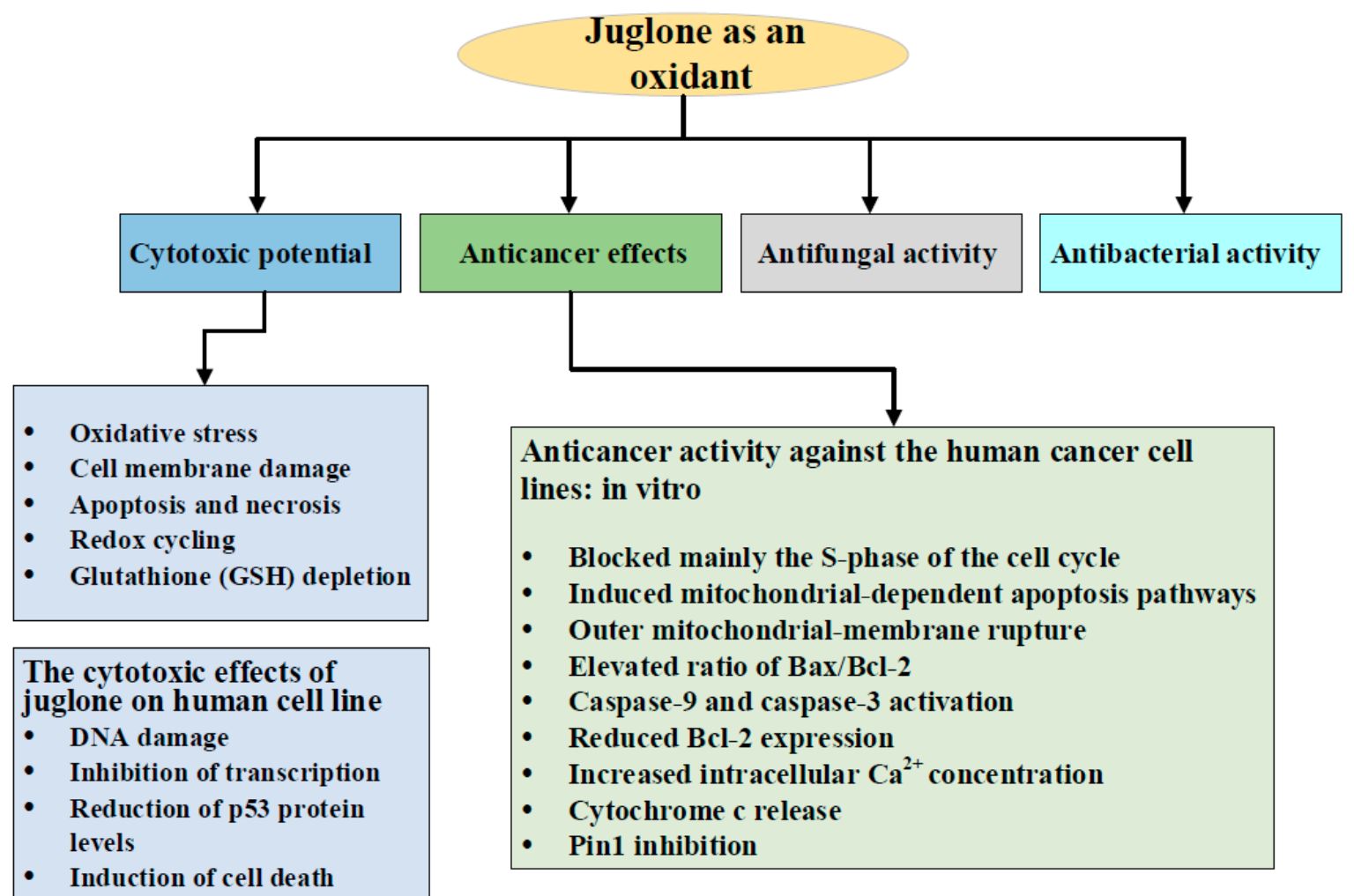

Figure 3. The schematic diagram showing the oxidant potential of juglone and its therapeutic applications.

\subsection{Anticancer Activity against the Human Cancer Cell Lines: in Vitro}

Juglone has been studied for its growth inhibitory effects on cultured malignant cells such as HCT-15 cells derived from human colon carcinoma and was found to block mainly the $S$ phase of the cell cycle [86]. Juglone induces apoptosis in HL-60 human leukemia cells [87], SGC-7901 human gastric cancer cells [88] and SKOV3 ovarian cancer cells [89] through mitochondrial-dependent apoptosis pathways and the elevated ratio of Bax/Bcl-2. The anti-cancer activity on LNCaP human prostate cancer cells indicated that juglone may be a potential candidate drug for androgen-sensitive prostate cancer [90]. The cytotoxic effect of juglone on human breast cancer cell line MCF-7 is characterized by elevated ROS levels, reduced Bcl-2 expression, increased Bax expression, decreased mitochondrial membrane potential, increased intracellular $\mathrm{Ca}^{2+}$ concentration, outer mitochondrial-membrane rupture, cytochrome c release, and caspase-3 activation [91]. According to a recent study, juglone significantly inhibits the proliferation and induces the apoptosis of human bladder carcinoma cell lines (TCC-SUB and RT-4) [92].

\subsection{Glioma Cells}

Glioma is a type of tumor that starts in the glial cells of the brain or the spine [93]. Gliomas comprise about 30 percent of all brain tumors and central nervous system tumors, and 80 percent of all malignant brain tumors [94]. The available data indicates that peptidyl-prolyl cis/trans isomerase Pin1 is overexpressed in human glioblastoma multiforme specimens. Therefore, Pin1 inhibitors should be investigated as a new chemotherapeutic drug that may enhance the clinical management of human gliomas. Recently, juglone, a Pin1 inhibitor, was shown to exhibit potent anticancer activity in various tumor cells including U251 glioma cells, and it was observed to disrupt angiogenesis [31]. Juglone also exhibits the anticancer effects in glioma C6 cells by generating ROS through interaction with respiratory complex I [95]. 


\subsection{In Vivo Anticancer Effects of Juglone}

The effect of juglone on intestinal carcinogenesis in rats was examined through dietary exposure during the initiation phase. The data suggest that juglone could be a promising chemopreventive agent for human intestinal neoplasia [26]. Tumor progression in mice is inhibited by juglone, which triggers oxidative stress that leads to apoptosis and cell cycle detention, the suppression of hypoxia-inducible factor-1 alpha, and separation of glycolytic metabolism [77]. Therefore, additional studies are warranted to examine the clinical potential of juglone in human cancers.

\section{Antimicrobial Activity of Juglone}

\subsection{Antifungal Activity}

The juice of freshly macerated unripe hulls of the black walnut (Juglans nigra) has been used for many years in folk medicine as a treatment for localized, topical fungal infections [25,96]. The compound that may be responsible for the wide range of biological activities of Juglans nigra is juglone [25]. Wianowska et al. also showed the antifungal activity of juglone and walnut green husk extracts [97]. Juglone may be as effective as commercially available antifungal agents including zinc undecylenate and selenium sulfide [25].

\subsection{Antibacterial Activity}

Juglone has been shown to possess antibacterial activities [57,58], and reportedly inhibits Gram-positive bacteria, Staphylococcus aureus [98]. Juglone exhibits a selective antimicrobial activity against different sources of Staphylococcus aureus strains. Juglone has been considered to be a natural source for resistance-modifying activity in the same bacteria and as phytochemical constituents with antibiotic resistance-modifying activity [99]. It is also likely that the mechanisms of antifungal and antibacterial actions of juglone involve redox cycling [14]. A bioinformatics analysis has shown that bacterial proteins that participate in DNA, RNA and protein synthesis as well as in the tricarboxylic acid cycle are inhibited by juglone [98]. It has also been reported that the antifungal and antibacterial activities of juglone nanoparticles are higher than those of free juglone, indicating that the nanoparticle formulation may be a promising way to enhance the beneficial effects of juglone [100,101].

\section{Role of Juglone as an Inhibitor of Peptidyl-Prolyl cis/trans Isomerase, Pin 1}

Juglone is often used as an inhibitor of peptidyl-prolyl cis/trans isomerases that catalyzes the cis/trans isomerization of peptide bonds preceding prolyl residues [102]. Peptidyl-prolyl cis/trans isomerases can regulate protein phosphorylation and cell signaling [103]. Since the identification of the importance of human peptidyl-prolyl cis/trans isomerase Pin1 in Alzheimer's disease [104] through the modulation of Tau protein [45], Pin1 and juglone have gained considerable attention. As a result, and largely through studies using juglone, Pin1 has also been implicated in a wide variety of clinical conditions including immune response [105], allergy [106], cancer [107,108], hyperparathyroidism [109], rheumatoid arthritis [110], vascular pathology [111-115], diabetes [116], Parkinson's disease [117], and cardiac fibrosis [118-120]. There are numerous review articles already available on Pin1, and thus interested readers should refer to these articles that are found in PubMed and other sources.

\section{Effects of Juglone on Cell Signaling Pathways}

In addition, juglone has been reported to influence a variety of other cell signaling pathways. It was found to activate MAP kinases including ERK, JNK and p38 in skin cells [121], glioblastoma cells [122], cervical cancer cells [123], melanoma cells [30], hepatocellular carcinoma cells [124], and smooth muscle cells [125]. In particular, cell signaling modulations of MAP kinases by juglone have been attributed to the mechanism of the induction of apoptosis. Some studies have shown that the 
MAP kinase activation is dependent on the production of ROS [30,122-124], suggesting that the redox cycling of naphthoquinones may be responsible for the mechanism.

In contrast to the activation of MAP kinase pathways, juglone has been shown to suppress the Akt pathway. Fang et al. [28] reported that, in prostate cancer cells, juglone inhibits the Akt/GSK-3b/Snail pathway and the subsequent epithelial-mesenchymal transition process. Similarly, juglone potentiates the reduction of Akt phosphorylation induced by high glucose, leading to suppressed eNOS-dependent nitric oxide pathway in rat aortas [28,126]. Juglone was also found to reduce the Akt phosphorylation level in breast cancer cells that are resistant to the trastuzumab anti-cancer monoclonal antibody [127].

Another interesting effect of juglone is its ability to activate the $\mathrm{Ca}^{2+}$ channel activity of transient receptor potential ankyrin subtype 1 channel, TRPA1 [128]. TRPA1 is an irritant sensor and plays a key role in nociception, irritant sensing and mechanical sensation [129]. These authors showed that juglone and plumbagin (both of which possess a hydroxyl group at the 5 position), but not lawsone (that has a hydroxyl group at the 2 position), exhibited the agonist effects. Thus, the hydroxyl group at the 5 position likely plays a mechanistic role in this activity. Further, since neither extracellular nor intracellular application of catalase (a hydrogen peroxide scavenger) prevented the activation [128], it is not likely that redox cycling-mediated ROS production is involved in this mechanism.

\section{Conclusions}

Juglone, a phenolic compound found in walnuts, has been shown to exert both oxidant and antioxidant activities, to act as an inhibitor of Pin1, and to modulate cell signaling. These diverse actions may confer the possible health benefits of walnuts. Further, juglone may be useful as a therapeutic agent to combat various diseases and to promote health. Further studies are needed to examine the clinical potential of juglone. One limitation of the juglone research field is that published studies have not performed comprehensive structure-activity relationships. Therefore, it is unclear whether the effects of juglone are specific or are shared by other naphthoquinone molecules. Nevertheless, juglone is an exciting molecule both chemically and biologically, and we hope that this review article will help future research.

Author Contributions: Conceptualization, T.A. and Y.J.S.; Methodology, T.A. and Y.J.S.; Software, T.A. and Y.J.S.; Validation, T.A. and Y.J.S.; Formal Analysis, T.A and Y.J.S.; Investigation, T.A. and Y.J.S.; Resources, T.A. and Y.J.S.; Data Curation, T.A. and Y.J.S.; Writing-Original Draft Preparation, T.A. and Y.J.S.; Writing-Review \& Editing.

Funding: This work was supported in part by NIH (R01HL072844, R21AI142649, R03AG059554 and R03AA026516) to Y.S. The content is solely the responsibility of the authors and does not necessarily represent the official views of the NIH.

Conflicts of Interest: The authors declare no conflict of interest.

\section{References}

1. Carrion, J.S.; Fuentes, N.; Gonzalez-Samperiz, P.; Sanchez Quirante, L.; Finlayson, J.C.; Fernandez, S.; Andrade, A. Holocene environmental change in a montane region of southern Europe with a long history of human settlement. Quat. Sci. Rev. 2007, 26, 1455-1475. [CrossRef]

2. Fathi Azad, F.; Garjani, A.; Motevalian Naeini, A. Study of hypoglycemic activity of the hydroalcholic extract of juglans regia in normal and diabetic rats. Pharma Sci. 2006, 2, 13-17.

3. Ma, Y.; Njike, V.Y.; Millet, J.; Dutta, S.; Doughty, K.; Treu, J.A.; Katz, D.L. Effects of walnut consumption on endothelial function in type 2 diabetic subjects. A randomized controlled cross over trial. Diabetes Care 2010, 33, 227-232. [CrossRef] [PubMed]

4. $\quad$ Aronis, K.N.; Vamvini, M.T.; Chamberland, J.P.; Sweeney, L.L.; Brennan, A.M.; Magkos, F.; Mantzoros, C.S. Short-term walnut consumption increases circulating total adiponectin and apolipoprotein A concentrations, but does not affect markers of inflammation or vascular injury in obese humans with the metabolic syndrome: Data from a double-blinded, randomized, placebo-controlled study. Metabolism 2012, 61, 577-582. [CrossRef] [PubMed] 
5. Delaviz, H.; Mohammadi, J.; Ghalamfarsa, G.; Mohammadi, B.; Farhadi, N. A review study on phytochemistry and pharmacology applications of Juglans regia plant. Pharmacogn. Rev. 2017, 11, 145-152. [CrossRef]

6. Halvorsen, B.L.; Holte, K.; Myhrstad, M.C.; Barikmo, I.; Hvattum, E.; Remberg, S.F.; Wold, A.B.; Haffner, K.; Baugerød, H.; Andersen, L.F.; et al. A systematic screening of total antioxidants in dietary plants. J. Nutr. 2002, 132, 461-471. [CrossRef] [PubMed]

7. Pellegrini, N.; Serafini, M.; Salvatore, S.; Del Rio, D.; Bianchi, M.; Brighenti, F. Total antioxidant capacity of spices, dried fruits, nuts, pulses, cereals and sweets consumed in Italy assessed by three different in vitro assays. Mol. Nutr. Food Res. 2006, 50, 1030-1038. [CrossRef]

8. Espin, J.C.; Garcia-Conesa, M.T.; Tomás-Barberán, F.A. Nutraceuticals: Facts and fiction. Phytochemistry 2007, 68, 2986-3008. [CrossRef]

9. Vinson, J.A.; Cai, Y. Nuts, especially walnuts, have both antioxidant quantity and efficacy and exhibit significant potential health benefits. Food Funct. 2012, 3, 134-140. [CrossRef]

10. Nahrstedt, A.; Vetter, U.; Hammerschmidt, F.J. Composition of the steam distillation product from the leaves of Juglans regia. Planta Medica 1981, 42, 313-332. [CrossRef]

11. Hirakawa, K.; Ogiue, E.; Motoyoshiya, J.; Yajima, M. Naphthoquinones from juglandaceae. Phytochemistry 1986, 25, 1494-1495. [CrossRef]

12. Wichtl, M.; Anton, R. Plantes Thérapeutiques. Tradition, Pratique Officinale, Science et Thérapeutique, 2nd ed.; Librairie Eyrolles: Paris, France, 2003.

13. Sharma, N.; Ghosh, P.; Sharma, U.K.; Sood, S.; Sinha, A.K.; Gulati, A. Microwave-assisted efficient extraction and stability of juglone in different solvents from Juglans regia: Quantification of six phenolic constituents by validated RP-HPLC and evaluation of antimicrobial activity. Anal. Lett. 2009, 42, 2592-2609. [CrossRef]

14. Inbaraj, J.J.; Chignell, C.F. Cytotoxic action of juglone and plumbagin: A mechanistic study using HaCaT keratinocytes. Chem. Res. Toxicol. 2004, 17, 55-62. [CrossRef] [PubMed]

15. Colaric, M.; Veberic, R.; Solar, A.; Hudina, M.; Stampar, F. Phenolic acids, syringaldehyde, and juglone in fruits of different cultivars of Juglans regia L. J. Agric. Food Chem. 2005, 53, 6390-6396. [CrossRef] [PubMed]

16. Soderquist, C.J. Juglone and allelopathy. J. Chem. Educ. 1973, 50, 782-783. [CrossRef]

17. Moir, M.; Thomson, R.H. Naphthaquinones in Lomatia species. Phytochemistry 1973, 12, 1351-1353. [CrossRef]

18. Nageshwar, G.; Radhakrishnainah, M.; Narayana, L.L. Chemotaxonomy of Caesalpinia. Curr. Sci. 1984, 53, 813-814.

19. Lee, C.H.; Lee, H.S. Color alteration and acaricidal activity of juglone isolated from Caesalpinia sappan heartwoods against Dermatophagoides spp. J. Microbiol. Biotechnol. 2006, 16, 1591-1596.

20. Marichkova, L.; Kumanova, B. Isolation of flavonoids and some accompanying substances from the above-ground part of some Astragalus centralpinus family Leguminosae (Russian). Probl. Farm. 1981, 9, 63-74.

21. Walnut Toxicity. Available online: www.omafra.gov.on.ca/english/crops/facts/info_walnut_toxicity.htm (accessed on 25 February 2019).

22. Vogel, A.; Reinschauer, C. Ueber einen neuen organischen Körper in deu Fruchtschalen der Juglans regia. Neues Repertorium für Pharmacie 1856, 5, 106-110.

23. Stickney, J.; Hoy, P. Toxic action of black walnut. Trans Wis State Hort Soc. 1881, 11, $166-167$.

24. Auyong, T.K.; Westfall, B.A.; Russell, R.L. Pharmacological aspects of juglone. Toxicon 1963, 1, $235-239$. [CrossRef]

25. Clark, A.M.; Jurgens, T.M.; Hufford, C.D. Antimicrobial activity of juglone. Phytother. Res. 1990, 4, 11-14. [CrossRef]

26. Sugie, S.; Okamoto, K.; Rahman, K.M.; Tanaka, T.; Kawai, K.; Yamahara, J.; Mori, H. Inhibitory effects of plumbagin and juglone on azoxymethane-induced intestinal carcinogenesis in rats. Cancer Lett. 1998, 127, 177-183. [CrossRef]

27. Zhang, W.; Liu, A.; Li, Y.; Zhao, X.; Lv, S.; Zhu, W.; Jin, Y. Anticancer activity and mechanism of juglone on human cervical carcinoma HeLa cells. Can. J. Physiol. Pharmacol. 2012, 90, 1553-1558. [CrossRef] [PubMed]

28. Fang, F.; Chen, S.; Ma, J.; Cui, J.; Li, Q.; Meng, G.; Wang, L. Juglone suppresses epithelial-mesenchymal transition in prostate cancer cells via the protein kinase B/glycogen synthase kinase-3 $\beta /$ Snail signaling pathway. Oncol. Lett. 2018, 16, 2579-2584. [CrossRef] [PubMed]

29. Chobot, V.; Hadacek, F. Milieu-dependent pro- and antioxidant activity of juglone may explain linear and nonlinear effects on seedling development. J. Chem. Ecol. 2009, 35, 383-930. [CrossRef] 
30. Liu, X.; Chen, Y.; Zhang, Y.; Du, J.; Lv, Y.; Mo, S.; Liu, Y.; Ding, F.; Wu, J.; Li, J. Juglone potentiates TRAIL-induced apoptosis in human melanoma cells via activating the ROS-p38-p53 pathway. Mol. Med. Rep. 2017, 16, 9645-9651. [CrossRef] [PubMed]

31. Wang, J.; Liu, K.; Wang, X.F.; Sun, D.J. Juglone reduces growth and migration of U251 glioblastoma cells and disrupts angiogenesis. Oncol. Rep. 2017, 38, 1959-1966. [CrossRef]

32. Leopoldini, M.; Russo, N.; Chiodo, S.; Toscano, M. Iron chelation by the powerful antioxidant flavonoid quercetin. J. Agric. Food Chem. 2006, 54, 6343-6351. [CrossRef]

33. Leopoldini, M.; Marino, T.; Russo, N.; Toscano, M. Antioxidant properties of phenolic compounds: H-atom versus electron transfer mechanism. J. Phys. Chem. A. 2004, 108, 4916-4922. [CrossRef]

34. Tejero, I.; González-García, N.; González-Lafont, À.; Lluch, J.M. Tunneling in green tea: Understanding the antioxidant activity of catechol-containing compounds. A variational transition-state theory study. J. Am. Chem. Soc. 2007, 129, 5846-5854. [CrossRef] [PubMed]

35. van Acker, S.A.; de Groot, M.J.; van den Berg, D.J.; Tromp, M.N.; Donné-Op den Kelder, G.; van der Vijgh, W.J.; Bast, A. A quantum chemical explanation of the antioxidant activity of flavonoids. Chem. Res. Toxicol. 1996, 9, 1305-1312. [CrossRef] [PubMed]

36. Russo, N.; Toscano, M.; Uccella, N. Semiempirical molecular modeling into quercetin reactive site: Structural, conformational, and electronic features. J. Agric. Food Chem. 2000, 48, 3232-3237. [CrossRef] [PubMed]

37. Nenadis, N.; Sigalas, M.P. A DFT study on the radical scavenging activity of maritimetin and related aurones. J. Phys. Chem. A. 2008, 112, 12196-12202. [CrossRef] [PubMed]

38. Jin, R. A DFT study on the radical scavenging activity of juglone and its derivatives. J. Mol. Struct. Theochem 2010, 939, 9-13. [CrossRef]

39. de Castro, E.; Hegi de Castro, S.; Johnson, TE. Isolation of long-lived mutants in Caenorhabditis elegans using selection for resistance to juglone. Free Radic. Biol. Med. 2004, 37, 139-145. [CrossRef] [PubMed]

40. Bentes, A.L.; Borges, R.S.; Monteiro, W.R.; de Macedo, L.G.; Alves, C.N. Structure of dihydrochalcones and related derivatives and their scavenging and antioxidant activity against oxygen and nitrogen radical species. Molecules 2011, 16, 1749-1760. [CrossRef]

41. Leopoldini, M.; Russo, N.; Toscano, M. The molecular basis of working mechanism of natural polyphenolic antioxidants. Food Chem. 2011, 125, 288-306. [CrossRef]

42. Galano, A.; Mazzone, G.; Alvarez-Diduk, R.; Marino, T.; Alvarez-Idaboy, J.R.; Russo, N. Food antioxidants: Chemical insights at the molecular level. Annu. Rev. Food Sci. Technol. 2016, 7, 335-352. [CrossRef]

43. Gülçin, I.; Huyut, Z.; Elmastaş, M.; Aboul-Enein, H.Y. Radical scavenging and antioxidant activity of tannic acid. Arab. J. Chem. 2010, 3, 43-53. [CrossRef]

44. Tamafo Fouegue, A.D.; Ghogomu, J.N.; Bikélé Mama, D.; Nkungli, N.K.; Younang, E. Structural and antioxidant properties of compounds obtained from $\mathrm{Fe}^{2+}$ chelation by juglone and two of its derivatives: DFT, QTAIM, and NBO studies. Bioinorg. Chem. Appl. 2016, 2016, 8636409. [CrossRef]

45. Galas, M.C.; Dourlen, P.; Bégard, S.; Ando, K.; Blum, D.; Hamdane, M.; Buée, L. The peptidylprolyl cis/trans-isomerase Pin1 modulates stress-induced dephosphorylation of Tau in neurons. Implication in a pathological mechanism related to Alzheimer disease. J. Biol. Chem. 2006, 281, 19296-19304. [CrossRef]

46. Pandareesh, M.D.; Chauhan, V.; Chauhan, A. Walnut supplementation in the diet reduces oxidative damage and improves antioxidant status in transgenic mouse model of Alzheimer's disease. J. Alzheimers Dis. 2018, 64, 1295-1305. [CrossRef]

47. Li, J.H.; Zhu, H.J.; Huang, X.R.; Lai, K.N.; Johnson, R.J.; Lan, H.Y. Smad7 inhibits fibrotic effect of TGF- $\beta$ on renal tubular epithelial cells by blocking Smad2 activation. J. Am. Soc. Nephrol. 2002, 13, 1464-1472. [CrossRef] [PubMed]

48. Djamali, A. Oxidative stress as a common pathway to chronic tubulointerstitial injury in kidney allografts. Am. J. Physiol. Renal Physiol. 2007, 293, F445-F455. [CrossRef]

49. Reese, S.; Vidyasagar, A.; Jacobson, L.; Acun, Z.; Esnault, S.; Hullett, D.; Malter, J.S.; Djamali, A. The Pin 1 inhibitor juglone attenuates kidney fibrogenesis via Pin 1-independent mechanisms in the unilateral ureteral occlusion model. Fibrogenesis Tissue Repair 2010, 3, 1. [CrossRef]

50. Zhou, D.J.; Mu, D.; Jiang, M.D.; Zheng, S.M.; Zhang, Y.; He, S.; Weng, M.; Zeng, W.Z. Hepatoprotective effect of juglone on dimethylnitrosamine-induced liver fibrosis and its effect on hepatic antioxidant defence and the expression levels of $\alpha$-SMA and collagen III. Mol. Med. Rep. 2015, 12, 4095-4102. [CrossRef] 
51. Klotz, L.-O.; Hou, X.; Jacob, C. 1,4-naphthoquinones: From oxidative damage to cellular and inter-cellular signaling. Molecules 2014, 19, 14902-14918. [CrossRef]

52. Lown, J.W. The mechanism of action of quinone antibiotics. Mol. Cell. Biochem. 1983, 55, 17-40. [CrossRef]

53. Powis, G. Free radical formation by antitumor quinones. Free Radic. Biol. Med. 1989, 6, 63-101. [CrossRef]

54. Monks, T.J.; Walker, S.E.; Flynn, L.M.; Conti, C.J.; DiGiovanni, J. Epidermal ornithine decarboxylase induction and mouse skin tumor promotion by quinones. Carcinogenesis 1990, 11, 1795-1801. [CrossRef] [PubMed]

55. Ollinger, K.; Brunmark, A. Effect of hydroxy substituent position on 1,4-naphthoquinone toxicity to rat hepatocytes. J. Biol. Chem. 1991, 266, 21496-21503. [PubMed]

56. Parekh, H.; Chavan, S.; Chitnis, M. Modulation of the thiol pools by vitamin $\mathrm{K} 3$ and its effect on survival of sensitive and resistant murine tumor cells. Anticancer Drugs 1991, 2, 159-168. [CrossRef]

57. Tan, D.T.C.; Osman, H.; Mohamad, S.; Kamaruddin, A.H. Synthesis and antibacterial activity of juglone derivatives. J. Chem. Chem. Eng. 2012, 6, 84-89.

58. Zakavi, F.; Golpasand Hagh, L.; Daraeighadikolaei, A.; Farajzadeh Sheikh, A.; Daraeighadikolaei, A.; Leilavi Shooshtari, Z. Antibacterial effect of juglans regia bark against oral pathologic bacteria. Int. J. Dent. 2013, 2013, 854765. [CrossRef] [PubMed]

59. Anaissi-Afonso, L.; Oramas-Royo, S.; Ayra-Plasencia, J.; Martín-Rodríguez, P.; García-Luis, J.; Lorenzo-Castrillejo, I.; Fernández-Pérez, L.; Estévez-Braun, A.; Machín, F. Lawsone, juglone, and $\beta$-lapachone derivatives with enhanced mitochondrial-based toxicity. ACS Chem. Biol. 2018, 13, 1950-1957. [CrossRef] [PubMed]

60. Paulsen, M.T.; Ljungman, M. The natural toxin juglone causes degradation of p53 and induces rapid H2AX phosphorylation and cell death in human fibroblasts. Toxicol. Appl. Pharmacol. 2005, 209, 1-9. [CrossRef] [PubMed]

61. Segura-Aguilar, J.; Jönsson, K.; Tidefelt, U.; Paul, C. The cytotoxic effects of 5-OH-1,4-naphthoquinone and 5,8-diOH-1,4-naphthoquinone on doxorubicin-resistant human leukemia cells (HL-60). Leuk. Res. 1992, 16, 631-637. [CrossRef]

62. Babula, P.; Adam, V.; Kizek, R.; Sladky, Z.; Havel, L. Naphthoquinones as allelochemical triggers of programmed cell death. Environ. Exp. Bot. 2009, 65, 330-337. [CrossRef]

63. Aithal, B.K.; Kumar, M.R.; Rao, B.N.; Udupa, N.; Rao, B.S. Juglone, a naphthoquinone from walnut, exerts cytotoxic and genotoxic effects against cultured melanoma tumor cells. Cell Biol. Int. 2009, 33, 1039-1049. [CrossRef]

64. d'Arcy Doherty, M.; Rodgers, A.; Cohen, G.M. Mechanisms of toxicity of 2- and 5-hydroxy-1,4-naphthoquinone; absence of a role for redox cycling in the toxicity of 2-hydroxy-1,4-naphthoquinone to isolated hepatocytes. J. Appl. Toxicol. 1987, 7, 123-129. [CrossRef]

65. Zhang, R.; Hirsch, O.; Mohsen, M.; Samuni, A. Effects of nitroxide stable radicals on juglone cytotoxicity. Arch. Biochem. Biophys. 1994, 312, 385-391. [CrossRef]

66. Lewis, D.C.; Shibamoto, T. Relative metabolism of quinones to semiquinone radicals in xanthine oxidase system. J. Appl. Toxicol. 1989, 9, 291-295. [CrossRef]

67. Xu, J.; Cheng, Q.; Arnér, E.S.J. Details in the catalytic mechanism of mammalian thioredoxin reductase 1 revealed using point mutations and juglone-coupled enzyme activities. Free Radic. Biol. Med. 2016, 94, 110-120. [CrossRef]

68. Kappus, H.; Sies, H. Toxic drug effects associated with oxygen metabolism: Redox cycling and lipid peroxidation. Experientia 1981, 37, 1233-1241. [CrossRef]

69. Kumbhar, A.S.; Padhye, S.B.; Jitender; Kale, R.K. Naturally occurring hydroxy napthoquinones and their iron complexes as modulators of radiation induced lipid peroxidation in synaptosomes. Met Based Drugs 1997, 4, 279-285. [CrossRef]

70. Gant, T.W.; Rao, D.N.; Mason, R.P.; Cohen, G.M. Redox cycling and sulphydryl arylation; their relative importance in the mechanism of quinone cytotoxicity to isolated hepatocytes. Chem. Biol. Interact. 1988, 65, 157-173. [CrossRef]

71. Bruins, J.J.; Albada, B.; van Delft, F. Ortho-Quinones and analogues thereof: Highly reactive intermediates for fast and selective biofunctionalization. Chemistry 2018, 24, 4749-4756. [CrossRef]

72. Babich, H.; Stern, A. In vitro cytotoxicities of 1,4-naphthoquinone and hydroxylated 1,4-naphthoquinones to replicating cells. J. Appl. Toxicol. 1993, 13, 353-358. [CrossRef] 
73. Meskelevicius, D.; Sidlauskas, K.; Bagdonaviciute, R.; Liobikas, J.; Majiene, D. Juglone exerts cytotoxic, anti-proliferative and anti-invasive effects on glioblastoma multiforme in a cell culture model. Anticancer Agents Med. Chem. 2016, 16, 1190-1197. [CrossRef] [PubMed]

74. Xu, H.L.; Yu, X.F.; Qu, S.C.; Qu, X.R.; Jiang, Y.F.; Sui, D.Y. Juglone, from Juglans mandshruica Maxim, inhibits growth and induces apoptosis in human leukemia cell HL-60 through a reactive oxygen species-dependent mechanism. Food Chem. Toxicol. 2012, 50, 590-596. [CrossRef] [PubMed]

75. Kviecinski, M.R.; Pedrosa, R.C.; Felipe, K.B.; Farias, M.S.; Glorieux, C.; Valenzuela, M.; Sid, B.; Benites, J.; Valderrama, J.A.; Verrax, J.; et al. Inhibition of cell proliferation and migration by oxidative stress from ascorbate-driven juglone redox cycling in human bladder-derived T24 cells. Biochem. Biophys. Res. Commun. 2012, 421, 268-273. [CrossRef]

76. Ourique, F.; Kviecinski, M.R.; Felipe, K.B.; Correia, J.F.; Farias, M.S.; Castro, L.S.; Grinevicius, V.M.; Valderrama, J.; Rios, D.; Benites, J.; et al. DNA damage and inhibition of Akt pathway in MCF-7 cells and Ehrlich tumor in mice treated with 1,4-naphthoquinones in combination with ascorbate. Oxid. Med. Cell. Longev. 2015, 2015, 495305. [CrossRef] [PubMed]

77. Ourique, F.; Kviecinski, M.R.; Zirbel, G.; Castro, L.S.E.P.W.; Gomes Castro, A.J.; Mena Barreto Silva, F.R.; Valderrama, J.A.; Rios, D.; Benites, J.; Calderon, P.B.; et al. In vivo inhibition of tumor progression by 5 hydroxy-1,4-naphthoquinone (juglone) and 2-(4-hydroxyanilino)-1,4-naphthoquinone (Q7) in combination with ascorbate. Biochem. Biophys. Res Commun. 2016, 477, 640-646. [CrossRef]

78. Sajadimajd, S.; Yazdanparast, R.; Roshanzamir, F. Augmentation of oxidative stress-induced apoptosis in MCF7 cells by ascorbate-tamoxifen and/or ascorbate-juglone treatments. In Vitro Cell. Dev. Biol. Anim. 2016, 52, 193-203. [CrossRef] [PubMed]

79. Lu, J.J.; Bao, J.L.; Wu, G.S.; Xu, W.S.; Huang, M.Q.; Chen, X.P.; Wang, Y.T. Quinones derived from plant secondary metabolites as anti-cancer agents. Anticancer Agents Med. Chem. 2013, 13, 456-463. [CrossRef] [PubMed]

80. Driscoll, J.S.; Hazard, G.F.; Wood, H.B.; Goldin, A. Structure-antitumor activity relationships among quinone derivatives. Cancer Chemother. Rep. 1974, 4, 1-362.

81. Verma, R.P. Anti-cancer activities of 1,4-naphthoquinones: A QSAR study. Anticancer Agents Med. Chem. 2006, 6, 489-499. [CrossRef]

82. Aubel-Sadron, G.; Londos-Gagliardi, D. Daunorubicin and doxorubicin, anthracycline antibiotics, a physicochemical and biological review. Biochimie 1984, 66, 333-352. [CrossRef]

83. Widhalm, J.R.; Rhodes, D. Biosynthesis and molecular actions of specialized 1,4-naphthoquinone natural products produced by horticultural plants. Hortic. Res. 2016, 3, 16046. [CrossRef]

84. Kayashima, T.; Mori, M.; Yoshida, H.; Mizushina, Y.; Matsubara, K. 1,4-Naphthoquinone is a potent inhibitor of human cancer cell growth and angiogenesis. Cancer Lett. 2009, 278, 34-40. [CrossRef]

85. Zhang, X.B.; Zou, C.L.; Duan, Y.X.; Wu, F.; Li, G. Activity guided isolation and modification of juglone from Juglans regia as potent cytotoxic agent against lung cancer cell lines. BMC Complement. Altern. Med. 2015, 15, 396. [CrossRef]

86. Kamei, H.; Koide, T.; Kojima, T.; Hashimoto, Y.; Hasegawa, M. Inhibition of cell growth in culture by quinones. Cancer Biother. Radiopharm. 1998, 13, 185-188. [CrossRef]

87. Xu, H.L.; Yu, X.F.; Qu, S.C.; Zhang, R.; Qu, X.R.; Chen, Y.P.; Ma, X.Y.; Sui, D.Y. Anti-proliferative effect of Juglone from Juglans mandshurica Maxim on human leukemia cell HL-60 by inducing apoptosis through the mitochondria-dependent pathway. Eur. J. Pharmacol. 2010, 645, 14-22. [CrossRef]

88. Ji, Y.B.; Qu, Z.Y.; Zou, X. Juglone-induced apoptosis in human gastric cancer SGC-7901 cells via the mitochondrial pathway. Exp. Toxicol. Pathol. 2011, 63, 69-78. [CrossRef]

89. Fang, F.; Qin, Y.; Qi, L.; Fang, Q.; Zhao, L.; Chen, S.; Li, Q.; Zhang, D.; Wang, L. Juglone exerts antitumor effect in ovarian cancer cells. Iran. J. Basic Med. Sci. 2015, 18, 544-548.

90. Xu, H.; Yu, X.; Qu, S.; Sui, D. Juglone, isolated from Juglans mandshurica Maxim, induces apoptosis via down-regulation of AR expression in human prostate cancer LNCaP cells. Bioorg. Med. Chem. Lett. 2013, 23, 3631-3634. [CrossRef]

91. Ji, Y.B.; Xin, G.S.; Qu, Z.Y.; Zou, X.; Yu, M. Mechanism of juglone-induced apoptosis of MCF-7 cells by the mitochondrial pathway. Genet. Mol. Res. 2016, 15. [CrossRef] 
92. Bayram, D.; Armagan, İ.; Özgöcmen, M.; Senol, N.; Calapoglu, M. Determination of apoptotic effect of juglone on human bladder cancer TCC-SUP and RT-4 cells: An in vitro study. J. Environ. Pathol. Toxicol. Oncol. 2018, 37, 173-181. [CrossRef]

93. Mamelak, A.N.; Jacoby, D.B. Targeted delivery of antitumoral therapy to glioma and other malignancies with synthetic chlorotoxin (TM-601). Expert Opin. Drug Deliv. 2007, 4, 175-186. [CrossRef] [PubMed]

94. Goodenberger, M.L.; Jenkins, R.B. Genetics of adult glioma. Cancer Genet. 2012, 205, 613-621. [CrossRef] [PubMed]

95. Sidlauskas, K.; Sidlauskiene, R.; Li, N.; Liobikas, J. 5-Hydroxy-1,4-naphthalenedione exerts anticancer effects on glioma cells through interaction with the mitochondrial electron transport chain. Neurosci. Lett. 2017, 639, 207-214. [CrossRef] [PubMed]

96. Bonjar, G.H.S.; Nik, A.K.; Aghighi, S. Antibacterial and antifungal survey in plants used in indigenous herbal-medicine of south east regions of Iran. J. Biol. Sci. 2004, 4, 405-412.

97. Wianowska, D.; Garbaczewska, S.; Cieniecka-Roslonkiewicz, A.; Dawidowicz, A.L.; Jankowska, A. Comparison of antifungal activity of extracts from different Juglans regia cultivars and juglone. Microb. Pathog. 2016, 100, 263-267. [CrossRef] [PubMed]

98. Wang, J.; Wang, Z.; Wu, R.; Jiang, D.; Bai, B.; Tan, D.; Yan, T.; Sun, X.; Zhang, Q.; Wu, Z. Proteomic analysis of the antibacterial mechanism of action of juglone against Staphylococcus aureus. Nat. Prod. Commun. 2016, 11, 825-827. [CrossRef] [PubMed]

99. Zmantar, T.; Miladi, H.; Kouidhi, B.; Chaabouni, Y.; Ben Slama, R.; Bakhrouf, A.; Mahdouani, K.; Chaieb, K. Use of juglone as antibacterial and potential efflux pump inhibitors in Staphylococcus aureus isolated from the oral cavity. Microb. Pathog. 2016, 101, 44-49. [CrossRef] [PubMed]

100. Arasoglu, T.; Mansuroglu, B.; Derman, S.; Gumus, B.; Kocyigit, B.; Acar, T.; Kocacaliskan, I. Enhancement of antifungal activity of juglone (5-hydroxy-1,4-naphthoquinone) using a poly (d,l-lactic-co-glycolic acid) (PLGA) nanoparticle system. J. Agric. Food Chem. 2016, 64, 7087-7094. [CrossRef]

101. Arasoglu, T.; Derman, S.; Mansuroglu, B.; Yelkenci, G.; Kocyigit, B.; Gumus, B.; Acar, T.; Kocacaliskan, I. Synthesis, characterization and antibacterial activity of juglone encapsulated PLGA nanoparticles. J. Appl. Microbiol. 2017, 123, 1407-1419. [CrossRef]

102. Hennig, L.; Christner, C.; Kipping, M.; Schelbert, B.; Rücknagel, K.P.; Grabley, S.; Küllertz, G.; Fischer, G. Selective inactivation of parvulin-like peptidyl-prolyl cis/trans isomerases by juglone. Biochemistry 1998, 37, 5953-5960. [CrossRef]

103. Jordens, J.; Janssens, V.; Longin, S.; Stevens, I.; Martens, E.; Bultynck, G.; Engelborghs, Y.; Lescrinier, E.; Waelkens, E.; Goris, J.; et al. The protein phosphatase 2A phosphatase activator is a novel peptidyl-prolyl cis/trans-isomerase. J. Biol. Chem. 2006, 281, 6349-6357. [CrossRef] [PubMed]

104. Hamdane, M.; Smet, C.; Sambo, A.V.; Leroy, A.; Wieruszeski, J.M.; Delobel, P.; Maurage, C.A.; Ghestem, A.; Wintjens, R.; Bégard, S.; et al. Pin1: A therapeutic target in Alzheimer neurodegeneration. J. Mol. Neurosci. 2002, 19, 275-287. [CrossRef]

105. Esnault, S.; Braun, R.K.; Shen, Z.J.; Xiang, Z.; Heninger, E.; Love, R.B.; Sandor, M.; Malter, J.S. Pin1 modulates the type 1 immune response. PLoS ONE 2007, 2, e226. [CrossRef]

106. Esnault, S.; Rosenthal, L.A.; Shen, Z.J.; Sedgwick, J.B.; Szakaly, R.J.; Sorkness, R.L.; Malter, J.S. A critical role for Pin1 in allergic pulmonary eosinophilia in rats. J. Allergy Clin. Immunol. 2007, 120, 1082-1088. [CrossRef] [PubMed]

107. Fan, G.; Fan, Y.; Gupta, N.; Matsuura, I.; Liu, F.; Zhou, X.Z.; Lu, K.P.; Gélinas, C. Peptidyl-prolyl isomerase Pin1 markedly enhances the oncogenic activity of the Rel proteins in the nuclear factor- $\mathrm{B}$ family. Cancer Res. 2009, 69, 4589-4597. [CrossRef]

108. Kim, G.; Khanal, P.; Kim, J.Y.; Yun, H.J.; Lim, S.C.; Shim, J.H.; Choi, H.S. COT phosphorylates prolyl-isomerase Pin1 to promote tumorigenesis in breast cancer. Mol. Carcinog. 2015, 54, 440-448. [CrossRef] [PubMed]

109. Nechama, M.; Uchida, T.; Mor Yosef-Levi, I.; Silver, J.; Naveh-Many, T. The peptidyl-prolyl isomerase Pin1 determines parathyroid hormone mRNA levels and stability in rat models of secondary hyperparathyroidism. J. Clin. Investig. 2009, 119, 3102-3114. [CrossRef] [PubMed]

110. Jeong, H.G.; Pokharel, Y.R.; Lim, S.C.; Hwang, Y.P.; Han, E.H.; Yoon, J.H.; Ahn, S.G.; Lee, K.Y.; Kang, K.W. Novel role of Pin1 induction in type II collagen-mediated rheumatoid arthritis. J. Immunol. 2009, 183, 6689-6697. [CrossRef] 
111. Chiasson, V.L.; Munshi, N.; Chatterjee, P.; Young, K.J.; Mitchell, B.M. Pin1 deficiency causes endothelial dysfunction and hypertension. Hypertension 2011, 58, 431-438. [CrossRef] [PubMed]

112. Costantino, S.; Paneni, F.; Lüscher, T.F.; Cosentino, F. Pin1 inhibitor Juglone prevents diabetic vascular dysfunction. Int. J. Cardiol. 2016, 203, 702-707. [CrossRef]

113. Liu, M.; Yu, P.; Jiang, H.; Yang, X.; Zhao, J.; Zou, Y.; Ge, J. The essential role of Pin1 via NF-kB signaling in vascular inflammation and atherosclerosis in $\mathrm{ApoE}^{-/-}$mice. Int. J. Mol. Sci. 2017, 18, 644. [CrossRef] [PubMed]

114. Lv, L.; Ye, M.; Duan, R.; Yuan, K.; Chen, J.; Liang, W.; Zhou, Z.; Zhang, L. Downregulation of Pin1 in human atherosclerosis and its association with vascular smooth muscle cell senescence. J. Vasc. Surg. 2018, 68, 873-883. [CrossRef] [PubMed]

115. Zhang, M.; Lin, L.; Xu, C.; Chai, D.; Peng, F.; Lin, J. VDR agonist prevents diabetic endothelial dysfunction through inhibition of prolyl isomerase-1-mediated mitochondrial oxidative stress and inflammation. Oxid. Med. Cell. Longev. 2018, 2018, 1714896. [CrossRef] [PubMed]

116. Lv, L.; Zhang, J.; Zhang, L.; Xue, G.; Wang, P.; Meng, Q.; Liang, W. Essential role of Pin1 via STAT3 signalling and mitochondria-dependent pathways in restenosis in type 2 diabetes. J. Cell. Mol. Med. 2013, 17, 989-1005. [CrossRef]

117. Ghosh, A.; Saminathan, H.; Kanthasamy, A.; Anantharam, V.; Jin, H.; Sondarva, G.; Harischandra, D.S.; Qian, Z.; Rana, A.; Kanthasamy, A.G. The peptidyl-prolyl isomerase Pin1 up-regulation and proapoptotic function in dopaminergic neurons: Relevance to the pathogenesis of Parkinson disease. J. Biol. Chem. 2013, 288, 21955-21971. [CrossRef]

118. Liu, X.; Liang, E.; Song, X.; Du, Z.; Zhang, Y.; Zhao, Y. Inhibition of Pin1 alleviates myocardial fibrosis and dysfunction in STZ-induced diabetic mice. Biochem. Biophys. Res. Commun. 2016, 479, 109-115. [CrossRef]

119. Wu, X.; Li, M.; Chen, S.Q.; Li, S.; Guo, F. Pin1 facilitates isoproterenol-induced cardiac fibrosis and collagen deposition by promoting oxidative stress and activating the MEK1/2-ERK1/2 signal transduction pathway in rats. Int. J. Mol. Med. 2018, 41, 1573-1583. [CrossRef] [PubMed]

120. Wu, D.; Huang, D.; Li, L.L.; Ni, P.; Li, X.X.; Wang, B.; Han, Y.N.; Shao, X.Q.; Zhao, D.; Chu, W.F.; et al. TGF- $\beta 1-P M L$ SUMOylation-peptidyl-prolyl cis-trans isomerase NIMA-interacting 1 (Pin1) form a positive feedback loop to regulate cardiac fibrosis. J. Cell. Physiol. 2019, 234, 6263-6273. [CrossRef] [PubMed]

121. Wahedi, H.M.; Park, Y.U.; Moon, E.Y.; Kim, S.Y. Juglone ameliorates skin wound healing by promoting skin cell migration through Rac1/Cdc42/PAK pathway. Wound Repair Regen. 2016, 24, 786-794. [CrossRef] [PubMed]

122. Wu, J.; Zhang, H.; Xu, Y.; Zhang, J.; Zhu, W.; Zhang, Y.; Chen, L.; Hua, W.; Mao, Y. Juglone induces apoptosis of tumor stem-like cells through ROS-p38 pathway in glioblastoma. BMC Neurol. 2017, 17, 70. [CrossRef]

123. Lu, Z.; Chen, H.; Zheng, X.M.; Chen, M.L. Experimental study on the apoptosis of cervical cancer Hela cells induced by juglone through c-Jun N-terminal kinase/c-Jun pathway. Asian Pac. J. Trop. Med. 2017, 10, 572-575. [CrossRef]

124. Wang, P.; Gao, C.; Wang, W.; Yao, L.P.; Zhang, J.; Zhang, S.D.; Li, J.; Fang, S.H.; Fu, Y.J. Juglone induces apoptosis and autophagy via modulation of mitogen-activated protein kinase pathways in human hepatocellular carcinoma cells. Food Chem. Toxicol. 2018, 116, 40-50. [CrossRef]

125. Shults, N.V.; Almansour, F.S.; Rybka, V.; Suzuki, D.I.; Suzuki, Y.J. Ligand-mediated dephosphorylation signaling for MAP kinase. Cell. Signal. 2018, 52, 147-154. [CrossRef] [PubMed]

126. Pektas, M.B.; Turan, O.; Ozturk Bingol, G.; Sumlu, E.; Sadi, G.; Akar, F. High glucose causes vascular dysfunction through Akt/eNOS pathway: Reciprocal modulation by juglone and resveratrol. Can. J. Physiol. Pharmacol. 2018, 96, 757-764. [CrossRef]

127. Sajadimajd, S.; Yazdanparast, R. Sensitizing effect of juglone is mediated by down regulation of Notch1 signaling pathway in trastuzumab-resistant SKBR3 cells. Apoptosis 2017, 22, 135-144. [CrossRef] [PubMed]

128. Hill, K.; Fiorito, S.; Taddeo, V.A.; Schulze, A.; Leonhardt, M.; Epifano, F.; Genovese, S. Plumbagin, juglone, and boropinal as novel TRPA1 agonists. J. Nat. Prod. 2016, 79, 697-703. [CrossRef] [PubMed]

129. García-Añoveros, J.; Nagata, K. TRPA1. Handb. Exp. Pharmacol. 2007, 179, 347-362. [CrossRef]

(C) 2019 by the authors. Licensee MDPI, Basel, Switzerland. This article is an open access article distributed under the terms and conditions of the Creative Commons Attribution (CC BY) license (http://creativecommons.org/licenses/by/4.0/). 